health, and particularly the problem of diseases which are transmissible from animals to man. Nearly one hundred diseases are known to be so transmissible, and additional ones are still being found. Some of these diseases are transmitted by direct contact of man with live animals, others are transmitted indirectly to people through the consumption of milk, eggs or meat. Diseases transmitted from animals to man are defined as 'zoonoses'. At present there are many international groups or agencies that are concerned with the control of the zoonotic diseases, but still closer collaboration is necessary between the medical and the veterinary professions in protecting man from zoonoses.

One subject which has not before been discussed was that of blood groups of domestic animals. In dogs, six distinct blood group factors are recognized.

As is the case with newly born babies, it is possible for newly born foals and pigs to die from hæmolytic disease, which is a pathological condition resulting from the union of maternal antibodies with blood-group factors of the red cells of the fotus.

There were several interesting contributions from Great Britain. Workers at the Research Institute for Animal Virus Diseases (Pirbright) reported new knowledge on living attenuated vaccines which gives hope of a method of combating foot-and-mouth disease in countries where it is widely spread. Footand-mouth disease is one of the most serious viral diseases affecting cattle in nearly every country of the world.

Workers of the Glasgow Veterinary School have reported successful trials with a vaccine produced against lung-worm infection, which causes great losses in cattle and sheep. Immunological basic work concerning parasites was reported by workers from Cam- bridge. They also demonstrated a correlation between immunity and chemotherapy. From the Cambridge Veterinary School there also came an important paper classifying respiratory diseases in poultry.

A paper on the international standardization of veterinary biological products was delivered by the director of the Veterinary Laboratory of the Ministry of Agriculture and Fisheries.

At a charming ceremony during the Congress the president of the Royal College of Veterinary Surgeons presented honorary associateships, awards usually made during the Congress, to five eminent foreign veterinary scientists.

The Spanish people were the most hospitable hosts and, in addition to the well-organized scientific site of the Congress, they had prepared a very full programme of evening receptions and other social funetions that were greatly enjoyed and appreciated by the members of the Congress. At the closing general session of the Congress an invitation conveyed by the German delegation to hold the seventeenth International Congress in Hanover, in order to celebrate there the centenary of the Congress which first started in Germany, was received with acclamation. The first International Congress on animal diseases was held in Hamburg in 1863 . It was initiated by an English veterinary surgeon, Prof. John Gamgoe. The principal subjects of discussion during the first congress were rinderpest, also called cattle plague, contagious pleuropneumonia of cattle and sheep pox. All these diseases ceased to exist in Britain many years ago.

The veterinary profession combating many devastating diseases of animals plays an important part, not only in the improvement of the health of animals, but also the health of man.

M. A. Soltys

\title{
PLANT GROWTH REGULATION
}

$\mathrm{T}$ HE fourth International Conference on Plant Growth Regulation was held at the Boyce Thompson Institute for Plant Research, Yonkers, Now York, during August 10-14. The Conference was sponsored jointly by the Institute and by the New York Botanical Garden and the Brooklyn Botanic Garden. The programme was co-ordinated with the ninth International Botanical Congress held in Montreal, Canada, during August 19-29.

The Conference was attended by many invited participants from seventeen countries. The United Kingdom was represented by sixteen participants. The last conference was held at Wye College (England) in 1955, and before that conferences were held at the University of Wisconsin in 1949 and in Paris under the auspices of the League of Nations in 1937.

The first day of the Conference was devoted to naturally occurring growth substances, the second to the gibberellins, the third to the synthetic auxins, and the fourth to other plant growth substances. Chairmen of the various sessions included, Prof. K. V. Thimann (Cambridge, Mass.), Dr. H. Burström (Lund, Sweden), Dr. P. W. Brian (Welwyn, England), Prof. F. Lona (Parma, Italy), Prof. R. L. Wain (Wye, England), Dr. J. Henderson ('Tuskegee, Alabama), Dr. P. E. Pilet (Lausanne, Switzerland) and Dr. J. van Overbeek (Modesta, California). Major evening addresses were given by Dr. William J. Robbins, director emeritus of the New York Botanical Garden, on the "Expanding Concepts of Plant Growth Regulation", and by Dr. James Bonner (California Institute of Technology) on the "Probable Future of "Auxinology' ",

In addition to the scheduled papers ample time was provided for discussion. The papers presented and the discussion remarks will be published in book form by the Iowa State College Press in May 1960. Copies will be sent to each participant and will be available to others at nominal cost.

Among the new advances reported at the Conference was the isolation of a new class of auxins from Maryland Mammoth tobacco by Dr. D. G. Crosby (Union Carbide Chemicals, South Charleston, West Virginia) and Dr. A. J. Vlitos (Caroni, Ltd., Trinidad, formerly at the Boyce Thompson Institute). About $10 \mathrm{mgm}$. of active chemicals were obtained from a ton of tobacco leaves and growing tips. One of the chemicals was identified as 1-docosanol and the other as a long-chain fatty acid not yet fully characterized. Bruce Stowe (Harvard) also presented results showing the growth-promoting activity of long-chain aliphatic compounds.

Prof. T. A. Bennet-Clark (University of London) reported on the effect of gravity on the distribution of auxins. The metabolism of indole auxins in plants was discussed by C. H. Fawcett, R. L. Wain and 
F. R. Wightman of Wye College. The isolation of a new acid from coconut milk which gives about half the stimulation produced by whole milk was reported by L. H. Weinstein, L. G. Nickell and W. J. Tulecke (Boyce Thompson Institute and Chas. Pfizer).

New concepts on the relation between structure and auxin activity with special reference to the requirements for reactions with necessary binding sites were discussed in separate papers by Prof. K. V. Thimann and Dr. J. van Overbeek. Some physical chemical aspects of synthetic auxins with respect to their mode of action were presented by Prof. V. Freed (Oregon).

This was the first international conference in which the gibberellins were discussed. The Japanese scientists who carried out some of the early work with the gibberellins, T. Hayashi, J. Kato and Yusuke Sumiki, were on hand to present their most recent results. Dr. P. W. Brian (Imperial Chemical Industries, Welwyn), who was a pioneer in directing the attention of the Western world to the Japanese discoveries and who has been very active in this field, reported on new developments from bis lab. oratory. Evidence showing the probable widespread occurrence of gibberellin-like substances in higher plants was presented by C. A. West (University of California).

A feature of the Conference was a memorial dinner to the late P. W. Zimmerman (Boyce Thompson Institute), who with his associate A. E. Hitchcock first tested 2,4-D for its effect on plant growth and development. Other chemicals first tested in his laboratory include indolebutyric acid and 1-naphthaleneacetic acid as well as a variety of substituted derivatives of benzoic acid and various substituted aryloxyacetic acids. P. W. Zimmerman was originally a member of the organizing committee for this Conference but became ill while on a business trip and died in August 1958 at the age of seventy-four.

Financial support for the Conference was given by the Rockefeller Foundation, the National Science Foundation, and fifteen industrial companies interested in agricultural chemicals. George L. McNew, managing director of the Boyce Thompson Institute, was chairman of the Organizing Committee for the Conference. A. J. Vlitos was secretary of the Organizing Committee and chairman of the Programme Committee.
Lawrence P. Miller

\section{THE BRITISH RAYON RESEARCH ASSOCIATION OPEN DAYS}

$\mathrm{T}$ HE British Rayon Research Association held the fourth of its annual open days during May 6-8. The total attendance was $900-1,000$, a marked increase on the two previous years. Encouraged by the favourable reception last year, the senior chemist and senior physicist again gave short lectures, after lunch on each day, illustrating the relevance of the basic research to current problems in the textile industry. Instead of endeavouring to demonstrate all the work of the Association, a limited number of current researches on topical problems were illustrated rather more fully than usual, and it is believed that this approach may have been, in part at least, responsible for the very high attendance. Two aspects<smiles>O=C[C@H](O)[C@H](O)[C@H](O)[C@H](O)CO</smiles>

Cellulose
The recent work on the alkaline degradation of cellulose has considerably strengthened the conclusions on the mechanism put forward previously. This mechanism can be summarized in the following reaction sequence :

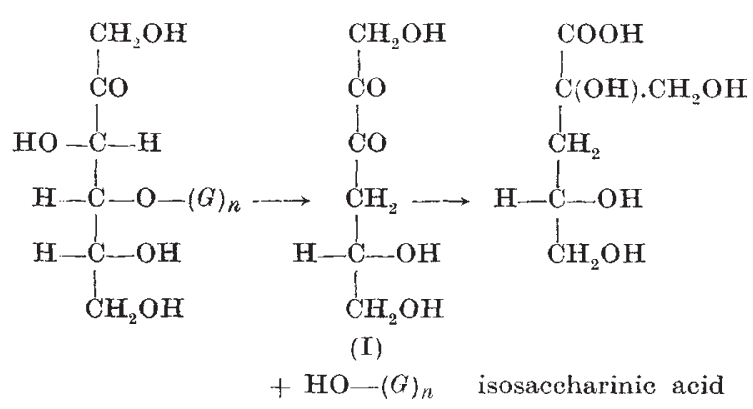

The intermediate (I) has now been isolated and its structure proved. The allkaline rearrangement of (I) is specifically catalysed by calcium and in lime water an almost theoretical yield of the isosaccharinic acid is obtained. The complex mixture of acids obtained with sodium hydroxide from this intermediate under the hot alkali-refining conditions used in purification of wood pulp is very similar, qualitatively and quantitatively, to that obtained from cellulose under the same conditions.

A considerable part of the resources of the Association are now directed to obtaining an understanding of the structure of textile fibres and attempting to correlate these with their physical, and particularly their mechanical, properties. On the chemical side a systematic study of the effect of known numbers of specific cross-links in cellulose and of substituents in specific regions, namely, crystalline or amorphous, of the cellulose on the mechanical properties has been 